\title{
MADURESE MILLENNIAL STUDENTS’ ANXIETY IN LEARNING ENGLISH
}

\author{
Mohammad Amiruddin*, Tanti Suparti \\ (Madura University)
}

\begin{tabular}{ll}
\hline A R T I C L E I N F O & A B S T R A C T \\
\cline { 2 - 4 } $\begin{array}{l}\text { Keyword: } \\
\text { Madurese, } \\
\text { anxiety, }\end{array}$ This study is to find out the models of Madurese millennial students' anxiety and the \\
millennial students, & factors causing the Madurese millennial students' anxiety in learning English. This \\
learning English & research is a qualitative research by using descriptive case study. The participants of \\
& the study are Madurese millennial students at English Department of Madura \\
& University. Observation and interviews with Madurese millennial students were \\
& conducted to get the data of the models and factors causing their anxiety. The results \\
& of the study indicate that Madurese millennial students experience two kinds of \\
& anxiety models those are interference and deficit models. Interference models are \\
& more dominants than deficit models. The teachers, friends, and abilities of Madurese \\
& millennial students are the factors causing their anxiety in learning English. The \\
& teachers are the first factors causing their anxiety. Their abilities in English become the \\
& second factor. However, it rarely happens to Madurese millennial students feel \\
& nervous when they are communicating with their peers. The communication in \\
& English become natural with no anxiety when they with their friends. Therefore, it \\
& implies that the teachers should propose the classroom activities providing facilities \\
& and helping the students to get meaningful input in English in order to overcome \\
& from their anxiety.
\end{tabular}

\section{INTRODUCTION}

Millennial invites societies to be familiar with the development of technology as well as the upgrading ways to communicate with others. This era makes you impossible to avoid English as a foreign language. In the millennial era, being a good communicator is important in particular students of English Department of Madura University. English is a foreign language of Madurese. Madurese students should have capabilities to communicate both in spoken and written English. They should master four kinds of skill in English such as listening, reading, speaking and writing. Mastering English is influenced by physicist factors such as embarrassed, less of confidence, fear of fault, worried, can disrupt someone's abilities on mastering the language.

Students' attitude, motivation, anxiety, and beliefs about foreign language learning have also been considered as factors that might affect the target language achievement. Gardner \& MacIntyre (1992) also state that language anxiety is a part of effective variables in second language acquisition. Anxiety is an ego function to remind someone about some possibilities of danger or something else outside of hope. Anxiety involves the feeling perception of something uninteresting and physiologist reaction, and it is a reaction on a situation that presented in danger. The characteristics of anxiety are somatic, emotional, cognitive, and behavioral components. Feeling unpleasant, distress, as well as embarrassment, happen to the students who experience anxiety. The success of students in English proficiency level is considered by the anxiety happen to them (Dordinejad and Ahmadabad, 2014). Students' emotional state, anxiety, and

\footnotetext{
${ }^{*}$ Corresponding author.

E-mail addresses: amiruddin@unira.ac.id (Mohammad Amiruddin), Kinan20ayu.nda@gmail.com (Tanti Suparti)
}

ISSN : 2597-7385 (Online) - ISLLAC : Journal of Intensive Studies on Language, Literature, Art, and Culture is licensed under Creative Commons Attribution-ShareAlike 4.0 International License (http://creativecommons.org/licenses/BY/4.0/). 
motivation facilitate students to success in English proficiency (Krashen, 2009). Students with lower anxiety level; they are possible to be better in English.

Cicek (2014) asserts that there are two anxiety models those are interference model and skills deficit model. The interference model consists of worry and emotionality. Worry happens to a cognitive concern of the individual's performance, but emotionality concerns to stress of students. Worry is the component affecting the academic activities of the students since it is negatively connected to performance and performance expectancy. It is considered to be the collection of negative uncontrollable thoughts, related to the fear of future outcomes. However, a skills deficit model is a model of anxiety caused by the capability of the students. They have poor acquisition of the language; it makes them being aware of anxiety and, consequently, they have weaker results in English performance.

Poor language acquisition invites the anxiety of the students. The students' anxiety is also considered by the teaching-learning process provided by the teachers. Mayangta (2013) states that anxiety affecting the students' performance in learning English, especially in speaking. The students in the EFL classroom are in high anxiety levels. They feel nervous to communicate in English to their teachers. They think that they are in danger when their teachers ask them to speak English.

Millennial students partly English department students of Madura University feel worried when the lecturer asks them about the materials that have been taught. Some of their lecturers ask them some question related to the previous subjects, so this condition makes the students in danger especially students who do not have preparation. They are also in high hesitant to present their papers in front of the class. Pauses in the middle of producing the language are common to the students. In addition, the students have difficulties to change the ideas into words since they are thinking about mistakes and punishments. They always lose the ideas the students want to produce to give opinions and comments to their teachers and peers. Moreover, they have no self-confidence to speak English in public. Their nervousness affects their performance in producing the English language. Consequently, it is important to discuss more details about the Madurese millennial students' anxiety as well as the factors affect their anxiety. The teachers take the important role to decrease the students' anxiety level in the millennial era in order to create a conducive atmosphere in the classroom making the students have more motivation to learn and communicate in English.

\section{METHOD}

This study is a qualitative research by using a descriptive case study. This research describes in details Madurese millennial students' anxiety as well as the factors causing the anxiety in learning English. The participants of this study are Madurese millennial students of English Department of Madura University. They are chosen by using a convenience sampling technique. They are near and easy to get as well as handy as well as they are ready to be a part of the sample. To get the data of Madurese millennia students' anxiety in learning English, this study uses observation and interview. Before making a conclusion, identification and simplification of the data are used in this study.

\section{RESEARCH FINDING AND DISCUSSION Research Findings}

Based on the observation and interview, the Madurese millennial students experience anxiety. They are nervous and worry to communicate in English. They experience two models of anxiety. They are interference and deficit models. Table 1 shows the models of Madurese millennial students' anxiety.

\section{Table 1. The Models of Madurese Millennial Students' Anxiety}

\begin{tabular}{llll} 
No. & Level of Anxiety & Frequency & Percentage \\
\hline 1. & Interference Model & 8 & $80 \%$ \\
\hline 2. & Skill Deficit Model & 2 & $20 \%$ \\
\hline Total & & 10 & $100 \%$ \\
\hline
\end{tabular}

Table 1 shows that the interference model experiencing more common than skill deficit models. $80 \%$ of Madurese millennial students experience worry and feel stress to communicate in English. It is caused by the environment of the students in language learning. In contrast, $20 \%$ of Madurese millennial 
students experience a deficit model of anxiety. The language environment of the students does not consider their anxiety. The students repeat their utterances and have many pauses since the classroom does not facilitate meaningful input.

The environment of language learning and the skill of students in English affect their performance in English. When the classroom does not help them to have much input, the anxiety is coming to their performance. Madurese millennial students who have not enough input in the target language, they will have many pauses, repetitions, as well as errors in performing English. They experience high hesitant when they have no enough input to communicate in English. Table 2 describes the factors causing Madurese millennial students' Anxiety.

Table 1. The Factors Causing the Madurese Millennial Students' Anxiety

\begin{tabular}{llll} 
No. & Factors of Anxiety & Frequency & Percentage \\
\hline 1. & Lecturers & 5 & $50 \%$ \\
\hline 2. & The ability of the students & 3 & $30 \%$ \\
\hline 3. & Friends & 2 & $20 \%$ \\
\hline Total & & 10 & $100 \%$ \\
\hline
\end{tabular}

Table 2 shows that factors causing the Madurese millennial students' anxiety are the lecturers, the ability of students in English, and the peers. They are considering the students' hesitant in English. 50\% Madurese millennial students say that the first factor causing their anxiety is the lecturer. The students have no confidence and motivation to speak English when the teaching methods of the teachers are students centered. The teachers' behavior has to do to their performance in English as well. When the teachers do not give smile and close in psychology to the students, they will have high anxiety level. 30\% of Madurese millennial students assert that the students' capability in English becoming the second factors in students' anxiety. This can increase the students hesitant to communicate in English. The last factors causing the students anxiety is their peer. It becomes the lowest factors causing the students' anxiety. $20 \%$ students state that communicating with their friends in public or in front of the class inviting their anxiety too.

\section{Discussion}

The interference model is the first anxiety models experienced by Madurese millennial students. The components of this model are worry and emotionality. It becomes negative thoughts connecting to performance and to the fear of future outcomes. Madurese millennial students feel anxious when they think about their English learning progress and the result in the future. They worry about the score at the end of each semester. They are afraid of getting bad results at the end of the subjects. It gives impact to their behavior in class, especially in English class. The behaviors show that they are getting worried. The pressure of the environment such as their teachers, friends, and teaching-learning methods used by the teachers is also the characteristics of this model. The students feel stress in learning English. The second model of anxiety is a skill deficit model. The students belong to the deficit model since their insufficient skill in English. It leads students to excessive negative thinking, self-doubt, and always feels inferior. It can make the student lose self-confidence and disrupt the student learning progress.

Vera is the first participants of the study. She is one of the Madurese millennial students of English Department of Madura University who gets anxiety in the class. She is worried about their English. She has many pauses and sometimes she is mixing the code. When the lecturer invites her to give questions to her friends, Vera often falters and sighs with nervousness. She also often stops to think what words she should say next because she is too nervous and suddenly switch to Indonesian. The following quotation is the example of Vera utterances.

Vera : According to your opinion, what is the ... see ... apa siiihhh! The advantages and disadvantages of the technology, and how to ... to... apa sih bahasa inggrisnya 
mengurangi? (While sighing and looking shaky).

Ika is the second participant of the research. Ika gives a question to her friends presenting about alcohol. The following is the quotation.

Ika : $\quad \begin{aligned} & \text { There is aa.... Apa yaa? Aaa... advantage, advantage of } \\ & \text { alcohol, yaa... }\end{aligned}$
Ifa : $\quad$ you'are asking, aren't you? It should be "is there?"
Ika : $\quad$ oh ya, is there... is there an advantage of alcohol?

Based on the quotation above, Ika is trying to convey her question to her friend in front of the class, but she used a wrong grammar in her question. Fortunately, there was her friend who told her about the better grammar. Ika looked relax enough while delivering her question, but a little bit anxiety perhaps made her forget to use a good grammar.

The third subject of the study is Laila Rufaidah. Laila is also had high hesitant making the errors of the utterances as well as changing to Indonesian code. The following quotation is the utterances of Ila when she gives the question to Isma.

Ila : Apakah there is a boarding schools in the other country like cairo or Arabic. As far as we know that is state of Islam.

Another example is presented by Uswatun Hasanah who becomes the fourth subject of this study. The following describes the utterances produces by Uswatun.

Uswatun : I think.. a..aa.. like mobile or hand phone because aa..aaa a.. (her voice sounded nervous and began to sweat and immediately explained by using Indonesian and not using English).

In the first meeting, Uswatun Hasanah presents her material in front of the class. She experiences a very high anxiety because when she tried to explain what her friend asked, she is bricked and her voice sounded nervous. She also repeated some words and sweats, and more silent during the discussion in her presentation. It makes her not able to deliver her English confidently in front of the audiences. Moreover, she has to face her friends and her lecturer.

In the second meeting Isma as a presenter or resource person who presented in front of the class, giving material about Indonesian religion in the world. At the time of explaining, Isma read more than explains with her own Language and when the question \& answer sessions are getting nervous about answering questions from her friends. The following is the quotation.
Sofiyah :
Ok I have two question for you
The first one is do all Islamic boarding schools in Indonesia have the same rules as having to settle in boarding school during study or just following the lesson? Indonesian and not using English).
The second one is what is the function of "Kiai" in the boarding school whether to teach in the cottage?
Isma : In Gondongan, not necessarily all settled in the cottage. They just... eee eeee eeee...apa ituuu.... (While wiping his head with a trembling voice and wiping the sweat on his forehead)
"Kiai" here ada yang mengajar ada juga yang hanya mengawasi kegiatan belajar mengajar di pesantren.

At the time of explaining the rules in Islamic boarding school Isma often rubes her forehead because of sweating and sigh long. Sometimes her vision looks as if she was looking for something and finally covered her face. Isma has prepared the material well but suddenly when she presents the materials in front of her lecturer, she has no ideas. 
There are students who convey that they actually have no ability in English. One of them is Haslindah, who is usually called Linda. She could not compose her own words to deliver the content of the materials. Because of her anxiety, she mostly uses Indonesian and Madurese. She is rarely using English. The following is the example of quotation.

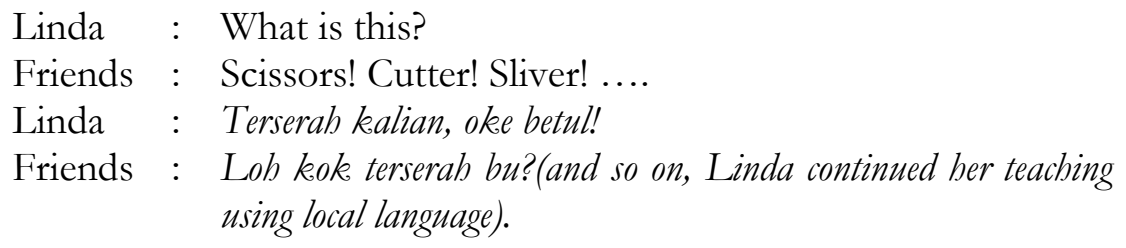

She has a less English capability. That's why she is more comfortable to use Indonesian or her mother tongue. She uses English only when the lecturers ask them to use English.

The anxiety of Madurese millennial students is caused by some factors those are teachers, the students' friends, and the capabilities of the students to communicate in English. They often feel anxious when talking or show something related to English in front of their lecturers. This relates to the way the lecturer teaches in the classroom as well as their interactions with the students. The following is a quotation

Ika states that her anxiety in producing English was also influenced by the presence of lecturers. If she has to convey something in English in front of the lecturer, then she will feel nervous, afraid, or anxious, even she lost her confidence. The following is the citation.

$\mathrm{R}$ : In what subject do you have low anxiety?

P : hmmm, depends on the lecturer

$\mathrm{R} \quad$ : it's meant that you have a problem with lecturer, you are afraid or shy maybe?

$\mathrm{P} \quad$ : when I face to face with my lecturer I feel nervous and not confident

$\mathrm{R}$ : Okay... in what subject do you have high anxiety?

$\mathrm{P} \quad$ : In language testing subject, because of the lecturer. Actually he is kind person but I don't know why. I just feel not confident when producing English in front of him.

Laila Rufaidah also asserts that the lectures are one of the factors of students' anxiety. She feels anxiety when speaking English in front of her lecturer. The anxiety that she faces often arises when she is not ready for the material to be delivered. Then she says that the anxiety is due to the lecturer.

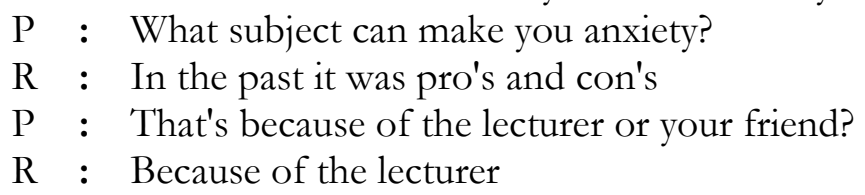

Students' anxiety is also caused by the behavior of friends against those who make mistakes in English. They claim that the uneasy feeling arises when their friends laugh at those who make some mistakes and errors in English In The students were in nervous when their friends have no support to them to speak English. The following mentions the information.

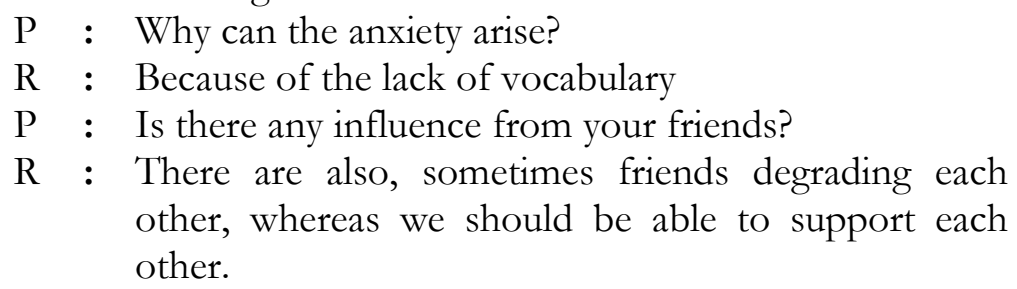


Anxiety experienced by Madurese millennial students of English department also is caused by the inability of individual learners in English. Although they are studying in the English department, it does not guarantee that they are very good at mastering English.

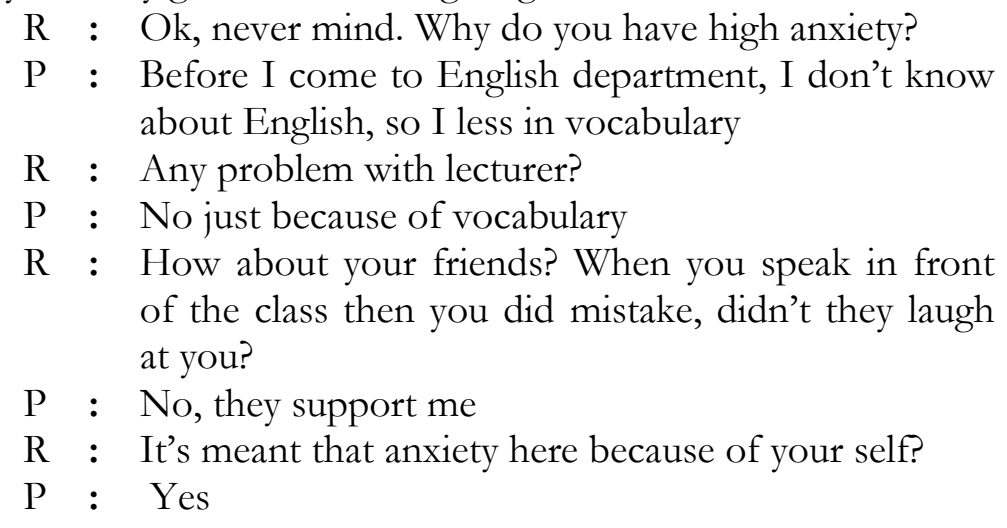

Sofia notes that the difficulties including her anxiety in communicating English are caused by her ability in performing English. When the students have limited vocabularies, never interact with English such as reading material, etc, the students will experience anxiety since they have no ideas to be produced.

Moreover, Linda admits that she has a very high anxiety when speaking English because of her insufficient English skills. Although in our dialogue, Linda also has anxiety because she rarely practices speaking English, the anxiety experienced by Linda comes from the inability of individual learners in English. The consequences of this incapacity eventually spread to other problems such as the interaction between the individual with others. The following is the statement of Linda.

$\mathrm{P}$ : Can you tell me how you feel when you enter in class?

$\mathrm{R}$ : There is a bad felling, there is a sense of tension, because from the beginning I am not from the English class. I moved from another class. So I don't have a sufficient basic English language.

To provide Madurese millennial students who have high anxiety levels with conducive classroom activities, it is important for the teachers identifying their models of anxiety as well as formulating some treatment based on the characteristics of each model in order to uncover their problems related to anxiety. Chaokongjakra (2013) the teachers should detect the reason for students' anxiety and try to facilitate them the affective classroom environment. Consequently, Madurese millennial students will learn to communicate in English rather than feeling nervous.

The achievements of Madurese millennial students are influenced by the anxiety experienced by them. Anxiety takes the important part in language learning. It is possible for Madurese millennial students having poor performance in English when they are in high hesitant to speak English. High nervousness in learning English brings negative effects on the success of the language acquisition process (Ewald, 2007). The feeling of worry comes to Madurese millennial students when they experience anxiety in speak English. Yan and Horwitz (2008) assert that peers' behavior, learning strategies, and learning interest considering relations to the student's motivation in learning English.

To help the Madurese millennial students overcome from their anxiety, it is essential for the students and academic society to design the environment of the teaching-learning process with an interesting mood. It believes that the anxiety experienced by the students influenced by the classroom atmosphere (Wang, 2003). The classroom does not help the students in learning English when it makes the students have lost the confidence, escaping from participating communication in English, losing their trust in the abilities and having no struggle to learn English. It causes the students to get low proficiency level in English. This situation becomes new factors to the students' anxiety in learning English. Therefore, it is important for the students to acculturate with people who have high frequencies in the target language to reduce their anxiety (Tang, 2005). 
Hashemi and Abbasi (2013) note that the ways to uncover Madurese millennial students' anxiety are providing the students with the classroom environment focusing on communication and activities between the teachers and the students. It is believed that this can avoid students to be less anxious and stress in language learning. When the focus of the class is manipulating the grammatical constructions in English, the students are thinking that the classroom environment is more formal and stressful. Making mistakes in producing English both in spoken and written when they are communicating to both their teachers and their peers in public, it becomes one of the factors causing the students anxiety.

Teachers and students interaction is significant in the millennial era. The interaction between the teachers and the students are able to create their intimacy in the teaching-learning process. It also makes the students' anxiety level come down and they will have the motivation to learn English. Amiruddin and Tafrilyanto (2018) discussing teacher-student closeness in learning English state that students' anxiety levels do not increase when they close to their teachers.

\section{CONCLUSION AND SUGGESTION}

\section{Conclusion}

Based on the finding and discussion, it concludes that the Madurese millennial students experience two models of anxiety those are interference and skill deficit models. The factors causing their anxiety are the lecturers, the abilities in English, and the peers. The interference model of anxiety is more dominant than skill deficit models. $80 \%$ of Madurese millennial students experience worry and feel stress to communicate in English. It is caused by the environment of the students in language learning. In contrast, $20 \%$ of Madurese millennial students experience a deficit model of anxiety.

The factors causing the Madurese millennial students' anxiety are the lecturers, the ability of students in English, and the peers. 50\% Madurese millennial students say that the first factor causing their anxiety is the lecturer. The students have no confidence and motivation to speak English in front of their teachers since they are considering mistakes and errors in English. 30\% of Madurese millennial students assert that the students' capability in English becoming the second factors in students' anxiety. The last factors causing the students anxiety is their peers. It becomes the lowest factors causing the students' anxiety. $20 \%$ students state that communicating with their friends in public or in front of the class inviting their anxiety as well.

\section{Suggestion}

It is suggested to the teachers and members of academic society to identify the models of students' anxiety as well as to provide treatment based on the models of anxiety experienced by the students and to design teaching-learning process with attractive atmospheres that help the Madurese millennial students uncovering their anxiety.

\section{REFERENCES}

Amiruddin, M. dan Tafrilyanto, F. C. (2018). Teacher-Students Closeness in Learning English at SMKMadhlatun Nasyiin Kadur Pamekasan. Jurnal Pendidikan Edutama, 5, 37-47.

Cicek, L. (2014). Language Anxiety - Causes And Consequences. Zagreb: University of Zagreb.

Ewald, J. D. (2007). Foreign language learning anxiety in upper-level classes: Involving students as researchers. Foreign Language Annals, 40 (1), 122-142.

Chaokongjakra W (2013). Speaking anxiety in foreign language learners. Thammasat University J. 31(2):182186.

Dordinejad FG, Ahmadabad RM (2014). Examination of the relationship between foreign language classroom anxiety and English achievement among male and female Iranian high school students. Int. J. Language Learn. Appl. Linguistics World 6(4):446-460.

Gardner, R. C., \& MacIntyre, P. D. (1992). A student's contributions to second language learning. Part I: Cognitive variables. Language Teaching, 25, 211-22.

Hashemi M, Abbasi M (2013). The role of the teacher in alleviating anxiety in language classes. Int. Res. J. Appl. Basic Sci. 4(3):640- 646 . 
Krashen, Stephen D. (2009). Principles and Practice in Second Language Acquisition. California: University of Southern California

Tang M. (2005). Survey and study of non-English major undergraduates' English learning anxiety in class. Taituan Normal University Journal (social science edition) 4, 145-146.

Wang Qi. (2003). A relative study of foreign language learning anxiety and classroom atmosphere and its teaching significance. Northwest Normal University Journal (social science edition) 6, 27-31.

Yan, J. X., \& Horwitz, E. K. (2008). Learners' perceptions of how anxiety interacts with personal and instructional factors to influence their achievement in English: A qualitative analysis of EFL learners in China. Language learning, 58(1), 151-183. 